\title{
ARTIKKELI
}

AULI VÄHÄKANGAS \& ANNA MÄKI-PETÄJÄ-LEINONEN

\section{\ Lähirelaatioiden vaikutus vainajan hautatahdon kunnioittamiseen}

\begin{abstract}
Abstrakti
Hautatahdossa on lain mukaan kyse vainajan autonomian ja katsomusten kunnioittamisesta. Tämä artikkeli analysoi läheisensä menettäneiden kertomuksia hautatahdosta ja siitä, miten he ovat pyrkineet huomioimaan vainajan tahdon hautajaisten suunnittelussa ja hautauspaikan valinnassa. Artikkelin aineisto muodostuu kolmentoista menetyksen kokeneen läheisen haastatteluista, jotka on analysoitu temaattisella sapluuna-analyysillä. Tulokset osoittavat, että osassa tapauksista vainaja oli selkeästi ilmaissut toiveensa hautaussuunnitelmista, mutta osassa tapauksista kyse oli oletetun hautatahdon kunnioittamisesta. Katsomukset vaikuttivat vainajan hautatoiveisiin erityisesti silloin kun hänellä oli ollut selvä uskonnollinen tai ei-uskonnollinen vakaumus. Vainajan, menetyksen kokeneen läheisen ja muiden läheisten relaatioilla oli iso merkitys vainajan hautatahdon seuraamisessa. Tutkimuksemme osoitti, että uusperhetilanne hankaloitti vainajan hautatahdon noudattamista erityisesti niissä tilanteissa, joissa läheisillä oli erilaisia tulkintoja vainajan toiveista. Johtopäätöksenä voidaan todeta, että vainajan selkeä toive hautausrituaalista, hautatavasta ja hautapaikasta helpottaa läheisten hautajaisiin liittyviä järjestelyjä ja säästää heitä turhilta riidoilta ja ikäviltä kokemuksilta hautajaisiin liittyen.
\end{abstract}

\section{Johdanto}

Yhä useampi ikäihminen kirjoittaa muistiin toiveitaan omaa kuolemaansa ja hautaamistaan varten ja tätä tarkoitusta varten löytyy myös valmiita malleja niin kutsutusta hautajaistestamentista (Suomen testamenttikeskus oy, 2020). Tästä kiinnostuksesta huolimatta monilla omaisilla on kova työ miettiä hau- 
tajaisia järjestäessään, mitä edesmennyt oikeastaan toivoi hautajaisiin liittyvien eri yksityiskohtien suhteen. Näitä toiveita voidaan yhteisnimellä kutsua hautatahdoksi. Hautatahdossa on lain mukaan kyse vainajan autonomian ja katsomusten kunnioittamisesta. Artikkelissa vastataan seuraaviin kysymyksiin: Miten läheisensä menettäneet ovat pyrkineet huomioimaan vainajan tahdon hautajaisten suunnittelussa ja hautauspaikan valinnassa? Miten lähirelaatiot vaikuttavat hautatahdon noudattamiseen?

Huolimatta länsimaisten yhteiskuntien individualisoitumiskehityksestä empiiriset tutkimukset ovat yhä uudestaan osoittaneet, että läheissuhteilla eli yksilön relaatioilla on edelleen suuri merkitys, erityisesti ikääntyneille ihmisille (Vaara ym., 2016; Tuominen \& Pirhonen, 2019). Sosiaalitieteellisessä tutkimuksessa on viime aikoina korostettu relationaalisuuden merkitystä yksilön hyvinvoinnin perustana. Suhteet toisiin ihmisiin ovat hyvinvoinnin rakentumisen kannalta keskeinen tekijä (Cottam, 2011). Relationaalisuuden näkökulmaan liittyy kuoleman lähestyessä läheisesti kysymys perhesuhteista (Vaara ym., 2016). Käsitykset perheestä ovat kuitenkin muuttuneet ja on olemassa monia erilaisia suhdemalleja. Perheet voidaan nähdä muuttuvina rakennelmina, joita yksilöt rakentavat jatkuvasti ja aina uudella tavoin (Jallinoja \&Widmer, 2011). Relationaalisuuden näkökulmaan liittyvät myös kysymykset läheissuhteiden vaikutuksesta vainajan toiveiden huomioimiseen. Näissä lähisuhteissa tulee ilmi, kuinka ikääntyvien leskien aikaisemmat parisuhteet vaikuttavat hautajaisten suunnitteluun ja vainajan hautaustoiveisiin (Moss \& Moss, 1996).

Ihmisen kohdatessa elämän muutoksia ja kriisejä kuten läheisen kuoleman, kokemus elämän merkityksellisyydestä voi horjua. Ihminen ajautuu tällöin merkityksen etsinnän prosessiin etsien elämäänsä uusia merkityksen lähteitä. Samalla olemassa olevista merkityksen lähteistä tulee entistä tärkeämpiä. (Baumeister, 1991; Schnell, 2009; Park, 2013.) Kriisissä ihminen tarvitsee ympärilleen läheisiä, sillä merkitykselliset ihmissuhteet antavat toivoa myös kuoleman kohtaamiseen. Toisinaan kuoleman lähestyminen aktivoi ihmisen suhdetta Jumalaan tai korkeimpaan voimaan (Zylla, 2012). Suhteet eli relaatiot ovat osaltaan ihmisten välisiä, osaltaan relaatiot pitävät sisällään (mahdollisen) suhteen Jumalaan tai korkeimpaan voimaan. Se miten suhteiden merkitys muuttuu tai kehittyy menetyksen jälkeen, riippuu yksilöiden taustalla olevasta merkityksellisyyden kokemuksesta ja keskeisistä elämän merkityksellisyyden lähteistä (Park, 2013). 
Relationaalinen teologia lähtee liikkeelle ajatuksesta, että yksilö on suhteessa toisiin ihmisiin ja osa ihmisistä tämän lisäksi myös suhteessa Jumalaan tai korkeimpaan voimaan (Cooper-White, 2004; McClure, 2010). Näissä eri suhteissa ihmiset pyrkivät tulemaan hyväksytyksi ja jakavat tarinoita tullakseen kuulluksi ja kohdatuksi. Tarinan kuuntelijoina voivat olla läheiset tai korkeampi voima (Ganzevoort 1998; Ganzevoort 2010). Relationaalisuudella on paikkansa myös oikeustieteessä, jossa individuaalisen autonomian rinnalle on kehittynyt ymmärrys relationaalisesta autonomiasta. Tämän näkökulman mukaan yksilön autonomia määräytyy suhteessa läheisiin ihmissuhteisiin; yksilö tekee päätökset relaatioidensa vaikuttamana ja hän voi saada läheisiltään myös tukea päätösten tekemisessä. (MacKenzie \& Stoljar 2000; Nedelsky 2011; Harding, 2012).

Vainajan hautatoiveita on Suomessa ja kansainvälisesti tutkittu jonkin verran. Aihetta on analysoitu persoonallisten hautajaisten näkökulmasta, jonka mukaan hautajaisissa halutaan huomioida vainajan persoona ja sitä kautta hänen tahtonsa (Schäfer, 2007; Ramshaw, 2010; Caswell, 2011). Katsomusten vaikutusta hautaukseen ja hautauspaikan valintaan on myös tutkittu, esimerkiksi katsomusten vaikutusta arkkuhautauksen ja tuhkauksen valintaan (Holm \& Lahtinen, 1985; Lahtinen, 1989; Davies, 2017). Tämän lisäksi on tutkittu uskonnollisten vähemmistöjen tilannetta uskontoantropologisessa projektissa, jossa tutkittiin juutalaisia hautajaisia ja tataarimuslimihautajaisia (Punta, 1978; Peltohaka, 1980). Valtaväestön katsomusten vaikutusta hautaustapaan ei kuitenkaan ole Suomessa tutkittu edellä esiteltyjen 1980-luvun arkkuhautausta ja tuhkausta käsitelleiden tutkimusten jälkeen. Kansainvälinen tutkimus on huomioinut sekularisaation vaikutuksen hautajaisiin tunnustuksettomien hautajaisten lisääntymisenä (Emke, 2010) ja laajemmin katsomusten vaikutuksen hautatapoihin ja -toiveisiin (Ladd, 2007; Holloway ym., 2013). Surututkimus tunnesiteen jatkumisesta (Klass ym., 1996; Valentine 2008; Klass 2006) keskittyi suhteen ylläpitämiseen vainajaan, mutta uudempi sosiologinen kuolematutkimus on huomioinut surevien keskinäisten suhteiden vaikutuksen hautajaisten suunnitteluun ja toteutukseen (Caswell, 2011; Ellis, 2013; Woodthorpe 2017). Oikeustieteen näkökulmasta hautatahtoa ei tietämyksemme mukaan ole juuri tutkittu. Hautajaisten suunnittelusta on kirjoitettu esimerkiksi ikääntyvien kuluttajien näkökulmasta (Frank,1996) tai siitä, miten hautausta koskevat erilaiset säännökset vaikuttavat tuhkauksen tai arkkuhautauksen valintaan (Harrington \& Krynski, 2002). 
Nyt käsillä olevassa artikkelissa lähestymme aihetta monitieteisesti teologian ja oikeustieteen näkökulmista, mikä antaa meille edellä esiteltyihin aikaisempiin tutkimuksiin nähden uuden tulokulman käsitellä vainajan toiveita hautajaisista ja hautapaikan valinnasta. Tarkastelemme seuraavaksi hautaustoimilakia, jossa on tarkempia säännöksiä vainajan toiveiden kunnioittamisesta.

\section{Hautatahto ja hautaustoimilaki}

Vainajan hautatahdon noudattamista voidaan tarkastella hautaustoimilain (HautL 457/2003) näkökulmasta. Hautaustoimilaissa säädetään ihmisen ruumiin hautaamisesta ja tuhkaamisesta, tuhkan käsittelystä sekä hautausmaan ja yksityisen haudan perustamisesta, ylläpidosta, hoitamisesta ja lakkauttamisesta sekä krematorion perustamisesta (HautL 1.1 §). Lain tavoitteena on edistää uskonnon- ja omantunnon vapauden toteutumismahdollisuuksia käytännössä ja turvata vainajan muiston kunnioittamiseen liittyvien pieteettinäkökohtien huomioon ottamista hautaustoimessa. Lain keskeisiä periaatteita ovat arvokkuuden ja kunnioittamisen vaatimukset ruumiin ja tuhkan käsittelyssä. Vainajan katsomusten ja toivomusten kunnioittamisen puolestaan tulee olla keskeisessä asemassa hautaamisessa, tuhkaamisessa ja tuhkan käsittelyssä (HE 204/2002).

Hautaustoimilaissa säädetään etusijajärjestyksestä hautajaisten järjestämisessä (HautL 23§). Kysymys on henkilöistä, joilla on ensisijaisesti oikeus huolehtia hautaamiseen, tuhkaamiseen ja tuhkan käsittelyyn liittyvistä järjestelyistä. Lain mukaan järjestys on seuraava: 1) vainajan nimeämä henkilö, 2) puoliso sekä lähimmät perilliset yhdessä, 3) lähimmät perilliset yksin, 4) muu läheinen tai 5) kunta. Laki lähtee siten hautajaisten järjestämisessä vainajan tahdon kunnioittamisesta. Jos vainaja on eläessään nimenomaisesti toivonut tietyn henkilön vastaavan hautausjärjestelyistä, ensisijaisesti tällä nimetyllä henkilöllä on oikeus huolehtia järjestelyistä.

Hautaustoimilaissa säädetään velvollisuudesta kunnioittaa vainajan katsomusta ja toivomuksia hautaamisessa, tuhkaamisessa ja tuhkan käsittelyssä (HautL 2.3 §). Kysymyksessä on vainajan autonomiaa korostava säännös ja tyypillisiä tilanteita, joissa säännös voi tulla sovellettavaksi, ovat lain esitöiden mukaan esimerkiksi valinta arkkuhautauksen ja tuhkauksen välillä, hautausmaan ja hautapaikan valinta sekä hautaustoimitus. Myös vainajan uskonnolli- 
nen tai muu katsomus tulee ottaa huomioon muun muassa harkittaessa hautaustoimituksen mahdollista uskonnollista sisältöä (HE 204/2002).

Vainajan toiveilla tarkoitetaan säännöksessä vainajan tiedetyn ja oletetun tahdon kunnioittamista. Tällä tarkoitetaan paitsi vainajan eläessään nimenomaisesti ilmaisemia toiveita, myös periaatetta, jonka mukaan hautausjärjestelyjä koskevia valintoja tehtäessä lähtökohdaksi tulee ottaa oletus siitä, mitä vainaja itse olisi toivonut (HE 204/2002, 12; ks. myös Mäki-Petäjä-Leinonen, 2003). Mahdollisten ristiriitatilanteiden varalle hautaustoimilakiin on sisällytetty säännökset menettelystä, jossa hautausjärjestelyjä koskevat kiistat voidaan ratkaista (HautL 23.4 §). Lain mukaan, jos hautajaiset ensisijaisesti järjestävät henkilöt (vainajan nimeämä henkilö, eloonjäänyt avio- tai avopuoliso ja lähimmät perilliset) eivät pääse yksimielisyyteen hautaamisen tavasta, paikasta tai hautaustoimituksesta, asian käsittelee se käräjäoikeus, jonka tuomiopiiriin vainajan kotikunta hänen kuollessaan kuului. Lain esitöiden mukaan käräjäoikeuden tulee asiaa käsitellessään ottaa huomioon lain 2 §ssä määritellyt hautaamiseen ja tuhkaamiseen sekä tuhkan käsittelyyn liittyvät yleiset periaatteet (HE 204/2002). Ensisijaisena lähtökohtana on siten vainajan katsomusten ja toivomusten huomioiminen. Kysymyksessä olevan, periaatetasoisen säännöksen juridinen merkitys korostuukin juuri riitatilanteissa, joissa tuomioistuin ratkaisua tehdessään pyrkii siihen, että vainajan tahto toteutuisi mahdollisimman hyvin (Mäki-Petäjä-Leinonen, 2013).

\section{Aineisto ja menetelmät}

Tämän artikkelin aineisto muodostuu kolmentoista menetyksen kokeneen läheisen haastatteluista, joista kahta on haastateltu kahteen otteeseen. Heistä suurin osa oli leskiä, yksi oli tytär ja yksi edesmenneen seurustelukumppani. Läheiset olivat 62-81-vuotiaita ja heistä neljä oli miehiä. Kaikki tämän artikkelin haastateltavat puhuivat äidinkielenään suomea ja olivat Suomessa syntyneitä. Suurin osa heistä kuului evankelis-luterilaiseen kirkkoon ja muutama identifioi itsensä ateistiksi. Läheiset on haastateltu melko pian menetyksen jälkeen, tästä syystä he muistavat hyvin hautaukseen liittyvät toiveet.

Aineisto on osa monitieteisen kotisaattohoitoa tutkineen Meaningful relations: Patient and family carer encountering death at home -hankkeen haastatteluaineistoa. Hankkeen taustalla olevat jo johdannossa esitellyt teoreettiset keskustelut elämän merkityksellisyydestä ja lähisuhteista vaikutti- 
vat käyttämäämme väljään haastattelurunkoon. Haastatteluiden keskiössä oli kotona tapahtunut saattohoitoprosessi ja siihen saatu tuki. Tämän lisäksi kysyimme, miten relaatiot tukivat tai haastoivat kokemusta elämän merkityksellisyydestä. Yksi keskusteluteema oli läheisen hiljattain olleet hautajaiset ja miten omat ja vainajan arvot vaikuttivat sen suunnitteluun ja toteutukseen. Haastateltavat rekrytoitiin julkisen ja yksityisen terveydenhuollon ja omaishoitajien liiton kautta sekä lehti-ilmoituksella eteläisessä Suomessa vuosina 2017-2019. Helsingin yliopiston Ihmistieteiden eettisen ennakkoarvioinnin toimikunnalta saatiin myönteinen lausunto tutkimuksen suorittamiseen, ja tämän lisäksi teimme eettiset selvitykset kaikkien yhteistyötahojen kanssa. Olemme nimenneet haastateltavat heidän syntymäaikansa yleisillä nimillä suojataksemme heidän yksityisyyttään.

Tutkimusaineisto litteroitiin kirjalliseen muotoon ja analyysi kohdentui tekstimateriaaliin. Ensimmäisessä vaiheessa analysoimme aineiston käyttäen temaattista sapluuna-analyysiä, jossa yhdessä koko kuusihenkisen tutkijatiimin kanssa kävimme läpi neljän menetyksen kokeneen läheisen haastattelut (2 miestä ja 2 naista) ja muodostimme näiden pohjalta menetyksen kokeneiden sapluunan (King \& Brooks, 2017). Kyseiset neljä läheisen haastattelua valittiin sapluunan pohjaksi, koska ne sisältävät erilaisia kuoleman ja saattohoidon kokemuksia. Aikaisempi metodikirjallisuus korostaa, että temaattinen sapluuna-analyysi on metodina hyvin joustava ja sitä on erityisesti käytetty tutkijatiimien yhteisissä analyyseissä (Brooks ym., 2015). Ennen yhteistä kokoontumista tiimin kuusi tutkijaa koodasi valitut litteraatiot ensin itsenäisesti ja vertasimme näitä koodeja tiimipalaverissa koodauksen validiteetin varmistamiseksi. Laatiessamme yhteistä sapluunaa jaoimme kyseiseen haastatteluun liittyviä yksityiskohtia ja kokosimme keskeisimmät teemat yhdessä rakentamaamme sapluunaan. Tässä vaiheessa työskentelimme hyvin perinteisesti tussien ja ison paperin kanssa keskittyen hastateltavien sanomisiin, mutta samalla kiinnittäen erityishuomiota tutkimusprojektille keskeisiin teoreettisiin keskusteluihin relaatioista ja elämän merkityksellisyydestä.

Tätä artikkelia varten ykköskirjoittaja teki aineiston tarkemman analyysin Atlas-ti laadullisen analyysin ohjelmalla koodaten koko aineiston. Kakkoskirjoittaja koodasi saman aineiston oikeustieteen näkökulmasta ja lisäsi kaksi koodia, relaatioiden positiivisen ja negatiivisen vaikutuksen, Atlas-koodeihin. Näiden erillään tehtyjen lisäanalyysien jälkeen tapasimme ja kävimme kaiken artikkeliin tulevan aineiston läpi ja keskustelimme tuloksista ja niiden 
merkityksestä yhdessä. Tämän artikkelin aineisto muodostui seuraavista neljästä pääteemasta: vainajan toiveet, hautajaiset, hautapaikka ja maailmankuva. Näistä ensimmäinen pääteema muodosti keskeisen aineiston, muista teemoista valittiin ne, joissa käsiteltiin vainajan toiveita ja katsomuksia kyseisiin teemoihin liittyen. Teemoja yhdistävänä keskusteluna toimivat relaatiot niin vainajaan kuin muihin menetyksen kohdanneisiin läheisiin.

Artikkelin rakenne noudattelee hautajaisten suunnittelu- ja toteutusprosessia. Seuraavassa alaluvussa käsitellään katsomusten vaikutusta vainajan hautausjärjestelyihin.

\section{Vainajan katsomusten vaikutus hautajaisjärjestelyihin}

Kuten edellä kerroimme, hautaustoimilain mukaan vainajan katsomus tulee ottaa huomioon hautaamisessa ja tuhkaamisessa sekä harkittaessa hautaustoimituksen mahdollista uskonnollista sisältöä. Tutkimusaineistostamme kävi ilmi, kuinka vainajan ja läheisen katsomukset ja maailmankuva vaikuttivat hautaamista koskeviin valintoihin. Suomalaiset eivät kuitenkaan ole tottuneet puhumaan katsomuksistaan julkisesti ja meidänkin haastatteluissamme suurin osa puhui näistä kiertoilmaisujen avulla tai esimerkkien kautta. Näin ei kuitenkaan ollut kaikkien kohdalla, vaan osalle oli luontevaa puhua katsomuksista ja niiden vaikutuksesta vainajan toiveisiin. Osa läheisistä kertoi vahvasta uskonnäkemyksestä, jonka avulla vainajan toive kristillisestä siunaustilaisuudesta oli selkeästi tiedossa. Eila kertoo uskon merkityksestä pariskunnan elämässä:

Ja sit uskonto oli, meillä oli molemmilla vahva uskonnäkemys, niin... Täs on lähikirkko ja siel on hirveen sellanen lämmin tunnelma, siellä on... Papit kättelee joka kerta kun jumalanpalvelus loppuu. Siel on oikeen sellanen, siel on meidän ystäviä paljon, ja nekin on ollu tosi sellasena läheisenä tukena mulla. Ja siel on melkeen aina kirkkokahvit ja sit tällasta vapaata seurustelua. Et siinäkin me oltiin, meil oli samanlaiset lähtökohdat kotoa.

Yhteinen uskonnollinen vakaumus vaikutti myös Eilan puolison siunaustilaisuuteen. Iso ystäväporukka saattoi puolison viimeiselle matkalle ja vainajan toiveiden mukaisesti siunaamaan oli pyydetty ennestään tuttu pappi. Eila kertoo tästä: 
Hän tuli siunaamaan sitten mun miehen, ja hän vielä teki niin poikkeuksellisen tilaisuuden siitä, että hän meni saarnastuoliin puhumaan ... niinku ennen siunausta, ja se hämmästytti näitä meidän ystäviä tosi paljon. Ja sit hän anto meille vielä muistoks sen oman puheensa, ja sekin on varmaan aika harvinaista.

Haastattelussa Eila ei kuvaa papin puheen sisältöä, vaan keskittyy tilanteen tunnelman kuvaamiseen. Tutun papin läsnäolo ja hänen tilanteen arvokkuutta korostava ele nousta ylös saarnastuoliin puhumaan, ovat jääneet Eilalle vahvasti mieleen. Hautajaiskertomuksesta näkyy ystävien merkitys Eilalle. Nämä edellä kuvatut ihmissuhteet, suhde pappiin ja suhde hautajaisissa oleviin ystäviin, olivat hänelle tärkeitä surun hetkellä.

Suurin osa läheisensä menettäneistä kuului evankelis-luterilaiseen kirkkoon, mutta ei kokenut omaavansa erityisen läheistä suhdetta kirkkoon. $\mathrm{He}$ eivät myöskään osallistuneet aktiivisesti kirkon toimintaan. Ilmari kertoo puolison suhteesta kristillisyyteen:

No hän oli tämmönen sunnuntaikristitty, niinku minäkin, että kirkon jäseniä ollaan, mutta ei voi sanoa että kauhean hengellisiä. Ei hän nyt missään tapauksessa ollut ateisti, vaan hänellä oli sellanen ehkä vähän laajempi käsitys näistä kuolemanjälkeisistä asioista, että ihminen jää elämään muistoissa ja hyvistä töistään, toivottavasti muistetaan hyvistä töistään paremmin kuin huonoista töistään, ja sitten tietysti juutalais-kristillinen sivistys on luonut meidän yhteiskuntamme eettisen pohjan länsimaissa ja tällä tavalla näin. Mutta ei hän kauheasti innostunut liturgioista, jos näin voi sanoa... Pikemminkin tämmöisestä arkipäivän hengellisyydestä.

Ilmarin tilanteessa vaimon arkipäivän hengellisyys näkyy hautajaisissa, joista kertoessa Ilmarille on keskeistä pappi ja hänen toimintansa:

Ne oli semmoset kauniit hautajaiset. Yksinkertaiset ja kauniit. Ja pappi piti oikein lämmittävän puheen, oli semmonen nuori naispappi, me tapasimme hänet vielä etukäteen tietysti, ja meidän nuorin poika ja vanhin tytär oli mukana, me käytiin kolmisin tapaamassa tätä pappia, ja hän oli tosi hyvä kanssa siinä. Että niistä jäi semmonen kuitenkin aika lämmin muisto kaikille, jotka oli siellä paikalla. 
Hautajaisista jäi Ilmarille lämmin muisto, vaikka hänkään ei kuvannut tarkemmin papin puheen sisältöä. Tulkintamme mukaan puhe ei ainakaan ollut puolison arvomaailman vastainen, vaan tuntui vahvistavan Ilmarin näkemystä vainajan katsomuksesta ja katsomuksen kunnioittamisesta myös hautaustoimilakia noudattavalla tavalla. Hautajaisista kertoessaan Ilmari kertoo luontevasti myös lähirelaatioiden merkityksestä kertoessaan, kuinka hän oli lastensa kanssa käynyt tapaamassa pappia hautajaisia suunniteltaessa.

Osa läheisistä ei jakanut vainajan maailmankatsomusta, heidän joukossaan on esimerkiksi Sirpa, joka kertoo haastattelussa miehensä ateismista:

Mun mieshän oli täysin ateisti. Ja mulla tietysti vanha, kotoo tulee, tämmönen ehkä joku taivaanisä, joku tämmönen. Mutta mäkään oo nyt mitenkään kauheen uskonnollinen, niin mä haluan mieluummin ehkä täällä vähän sitten muistella.

Sirpan mies ei ollut halunnut puhua lähestyvästä kuolemasta eikä perheellä ollut kovinkaan selvää kuvaa hänen toiveistaan. Yllä olevasta lainauksesta näkyy, että Sirpa itse toivoi paikkaa, jossa puolisoa voi muistella. Sirpan mies siunattiin kirkollisesti siunauskappelissa ja hänelle laitettiin muistolaatta hautausmaalle. Haastattelusta ei tule ilmi, toimiko Sirpa yhdessä lastensa kanssa tässä vainajan tahtoa vastaan vai eikö hänen ateismiinsa kuulunut näkemystä siitä, että häntä ei saa haudata kirkollisesti. Myös hautaustoimen tilastojen mukaan suurempi osa kirkkoon kuulumattomista siunattiin kirkollisesti haudan lepoon kuin jätettiin siunaamatta (Hautaustoimen tilasto, 2019).

Siitä huolimatta, että surevien läheisten haastatteluissa tuli ilmi, että useampi vainaja ei kuulunut kirkkoon, ainoastaan yksi vainaja oli haudattu uskonnottomien menoin. Kari kertoo puolisonsa uskonnottomasta hautajaistilaisuudesta:

Me kummatkaan ei kuuluta kirkkoon, että meillä oli tämmöset. Eka kerta kun mäkin oon ollu sellasissa hautajaisissa, mihin ei pappi tule, ja mulle jäi siitä tosi positiivinen kuva, että me järjestettiin itse, suunniteltiin tietenkin. Ensin he soitti sellasen alkumusiikin. Sen jälkeen poika piti tervetuliaissanat, missä hän vaan kertoi, mitä me nyt seuraavaks tehdään. Sitten me käytiin kaikki laskemassa ne omat kukkamme siihen ympärille, sehän on semmonen metalliteline siinä arkun ympärillä, ja sitten soitti taas tää 
trio. Sitten Ritvan miniä piti puheen. Sen jälkeen minä pidin puheen. Sitten se arkku liukui sinne ovien taakse ja musiikki soi.

Karille uskonnottomasta tilaisuudesta kertominen oli tärkeää ja hän koki pystyneensä noudattamaan vainajan tahtoa sen toteuttamisella. Karin tarina kertoo myös vahvoista relaatioista, siitä kuinka lähipiiri toteutti yhdessä hyvin persoonalliset hautajaiset. Kari ja Ritvan poika suunnittelivat ja järjestivät kaiken itse.

Seuraavaksi tarkastelemme lähemmin vainajan esittämiä toiveita ja niiden huomioon ottamista hautajaisten suunnittelussa.

\section{Vainajan hautajaisjärjestelyjä koskevat toiveet}

Vainajan katsomusten lisäksi ruumiin hautaamisessa ja tuhkaamisessa tulee hautaustoimilain mukaan kunnioittaa myös vainajan toivomuksia (HautL 2.3 $\S)$. Nämä toivomukset voivat olla paitsi nimenomaisesti ilmaistuja tahdonilmaisuja myös oletuksia vainajan toiveista (HE 204/2002, 12). Hautajaisjärjestelyt ja kaikki siihen liittyvät käytännön asiat tulivat esiin useimmissa haastatteluissa. Nämä nähtiin tärkeiksi ja niistä haluttiin kertoa myös haastattelijoille. Osa puolisoista oli suunnitellut omat hautajaisensa, seuraavassa Ilmari kertoo tästä:

Joo, hautajaisista puhuttiin, ja hän itse asiassa kirjoitti hautajaiskaavan itselleen ja sen mukaan mentiin. Ja hänellä oli siinä sitten apuna yks ystävä, toinen nainen, joka on vähän häntä nuorempi, jolle oli käynyt juuri samalla tavalla, että hänen miehensä kuoli syöpään. Ja tämä toinen nainen oli juuri sitten selvinnyt siitä ja järjestänyt tämän kuolleen miehensä hautajaiset. Ja vaimo ootti silloin hoitojansa ja sit he keskenänsä suunnitteli hänen hautajaisiaan.

Ilmarin kertomuksesta käy ilmi, kuinka relationaalinen autonomia, eli päätösten tekeminen läheisverkostojen tuella (Nedelsky, 2011; Harding, 2012), näyttäytyi vaimolle ystävyyssuhteessa. Hän sai apua ja tukea hautajaisjärjestelyihin omalta ystävältään, joka oli juuri kokenut puolisonsa menetyksen.

Ilmari ei ollut poikkeus aineistossamme vaan myös Markun vaimo suunnitteli tarkkaan omat hautajaisensa: 
Hänellä oli vahva luonne oli sitten, että hän ei sillai masentunu siitä, mutta kaikki hän suunnitteli etukäteen, niin ku hautajaiset... Ja ketä kututaan hautajaisiin ja se pietään sit tääl kotona sitten ja. Tästä just vaan, niin mä aattelen just niin ku hänen siskojaan sitten, että ehkä ne saatto pikkasen sitten siinä ottaa itteensä kun me ei kututtu heijän lapsiaan vaikka ne nyt on aikuisia ihmisiä, muuta kun hän kirjoitti ite listan ketä pyydetään ja sen mukaan me mentiin sitten.

Markku tuo kertomuksessaan esille puolisonsa individuaalista autonomiaa. Hänen vaimonsa oli suunnitellut hautajaisensa ilman, että oli suunnitelmissaan tukeutunut puolisonsa apuun. Markku myös koki tärkeäksi vaimonsa autonomian kunnioittamisen tavalla, jota hautaustoimilakikin vainajan katsomusten ja toivomusten osalta korostaa (HautL, 2.3 §). Vaikuttaa myös siltä, että Markku olisi mielellään kutsunut myös puolisonsa siskojen lapset hautajaisiin, mutta jätti tämän tekemättä, koska halusi noudattaa tarkasti edesmenneen puolisonsa toiveita.

Kaikissa tilanteissa vainaja ei suunnittele omia hautajaisiaan tai keskustele niitä koskevista toiveistaan läheistensä kanssa. Aihe saatetaan kokea liian kipeäksi tai ei vielä ajankohtaiseksi. Perheet voivat kuitenkin pyrkiä tällaisessa tilanteessa noudattamaan vainajan oletettuja toiveita. Tätä kuvaavat hyvin seuraavat Annelin kertomukset hautajaisten järjestämisestä.

Se meni mun mielestä just niinku Antti halus, mä koen sen niin että tää meni just niinku hän halus. Mä halusin että tehdään just niinku hän haluaa, vaik puhuttiin tyttöjen kanssa siitä et meil ei ollu koskaan puhetta siitä, että onko arkkuhautaus, vai uurnahautaus, mut me kaikki tiedettiin että kun Antin isällä oli uurnahauta... mut me tiedettiin että Antti halus just tämän saman mikä oli ollut hänen isällään. Et se oli niin itsestäänselvää.

Annelin puheesta käy hyvin ilmi, kuinka hänelle ja lapsille oli tärkeää pyrkiä noudattamaan puolison toiveita. Puolison toiveet uurnahautauksesta olivat heidän mielestään selviä ja samoin oli itsestään selvää, että toivetta kunnioitettiin. Tällä tavoin he - oletettavasti tietämättään - noudattivat myös hautaustoimilain periaatetta, jonka mukaan vainajan ilmaisemien toiveiden puuttuessa hautausjärjestelyjä tehtäessä lähtökohdaksi tulee ottaa oletus siitä, mitä 
vainaja itse olisi toivonut (HE 204/2002). Hautaustoimilaki onkin yksi harvoista laeista, jossa yksilön oletetun tahdon kunnioittaminen nähdään osaksi hänen itsemääräämisoikeuttaan (Mäki-Petäjä-Leinonen, 2003).

Vainaja voi esittää hautatahtonsa joko suullisesti, kirjallisesti tai se voidaan edellä mainituin tavoin ottaa huomioon vainajan oletetun tahdon ilmaisuna. Jos vainaja kuitenkin haluaa varmistaa, että toiveita kunnioitetaan, ne olisi hyvä tehdä kirjallisesti. Tätä kuvastaa Ritan kuvaus miesystävänsä hautapaikkaa koskevasta toiveesta. Miesystävän Ritalle suullisesti esittämän toiveen vastaisesti tämän lapset tekivät päätöksen hautapaikasta.

No, niissä tulikin, tulikin sitten, tulikin sitten kaikkea muuta kuin mitä piti tulla, koska ei oltu mitään ehditty tekemään paperille valmiiksi. Oli kyllä puhuttu selvästi, että mies sano, että hän haluaa jäädä Helsinkiin, mutta ei ehditty laittamaan mustaa valkoselle. Ja mä sitten sanoin pojille, että näin on puhuttu...Mutta pojat sitten päätti, että he haluaa hänet viedä sinne paikkakunnalle, missä hän on syntynytkin.

Rita kuvaa edesmennyttä miestä ystäväkseen ja kyse oli ilmeisesti seurustelusuhteesta ilman yhdessä asumista tai muuta virallisempaa suhteen muotoa. Tästä huolimatta Rita oli toiminut ystävänsä omaishoitajana saattohoidon aikana ja hän toivoi voivansa seurata vainajan toiveita hautapaikan suhteen. Miesystävän lapset päättivät kuitenkin toisin. Lähirelaatiot näyttivät siis myös vaikeuttavan vainajan toiveiden noudattamista, sillä lapsilla ei välttämättä ollut tietoa isänsä viimeisistä toiveista. Tämä vahvistaa aikaisempaa tutkimusta, jonka mukaan iäkkäiden leskien uudet parisuhteet saattavat vaikeuttaa hautajaisjärjestelyjä (Moss \& Moss, 1996).

Hautajaisten suunnitteluun kuuluivat siunaustilaisuuden suunnittelun lisäksi keskustelu vainajan toiveista liittyen hautaustapaan ja hautapaikkaan.

\section{Vainajan relaatioiden vaikutus hautaustapaan ja hautapaikkaan}

Vainajan katsomusten ja toivomusten kunnioittamisen lisäksi hautaustoimilain keskeisiä periaatteita ovat arvokkuuden ja vainajan muiston kunnioittamisen vaatimukset ruumiin ja tuhkan käsittelyssä (HautL 2.2 §). Säännöksen suojelukohteena ovat ennen kaikkea vainajalle lähteisten ihmisten tunteet ja 
ihmisten käsitys siitä, miten vainajiin tulee suhtautua (HE 204/2002). Monilla vainajilla ja heidän läheisillään oli selkeä näkemys siitä, tuliko hautaus suorittaa arkkuhautauksena vai tuhkauksena. Ruumiin käsittelyyn, hautatapaan ja hautapaikan valintaan liittyvissä valinnoissa yhdistyi teologinen ja oikeustieteellinen näkökulma relationaalisuuteen, sekä katsomusten että autonomian kunnioittaminen. Tämän lisäksi läheiset kertovat tarinoita siitä, mitä muita toiveita hautauspaikan valintaan liittyi. Surevien läheisten suhde vainajaan, heidän keskinäiset suhteensa sekä uusperhetilanteessa suhteet myös aikaisempiin puolisoihin ja lapsiin vaikuttivat näihin valintoihin.

Tuhkaus on viime vuosina yleistynyt ja siitä kerrottiin myös selvästi enemmän haastatteluissa kuin arkkuhautauksesta. Suomen evankelis-luterilainen kirkko pitää hautaustoimen tilastoja, joista ilmenee se, että vuonna 201944 \% hautauksista oli arkkuhautauksia ja loput tuhkauksia (Hautaustoimen tilasto, 2019). Arkkuhautausta ei montaakaan kertaan haastattelujen aikana mainittu, vaikka mitä ilmeisimmin useita vainajia oli haudattu perinteisellä arkkuhautauksella.

Aino kertoo puolisonsa arkkuhautauksesta:

Siis kun se oli se arkkuhautaus, niin siinä tietysti oli se hautapaikka... oli aika pitkään sit vähän... siin oli ne kukkaset mitkä oli haudalle laitettu... Tää tytär oli sitten vieny sinne omat, laittanu kukkasia, siinähän ei ollu vielä kiveekään laitettu... Ja sitten hän, se tuli kauheen myöhään se kivi, mut sille oli sit selitys, ku se oli arkkuhautaus, ni täytyy oottaa et se maa painuu, et muuten se kivi ei pysy siinä...

Ainon tarinan keskipiste ei ole arkkuhautaus valintana vaan miten tämän hautausmuoto vaikutti haudalla käymiseen. Hautapaikan valinnassa tärkeänä oli, että puoliso pääsi jo aiemmin edesmenneen puolison viereen sukuhautaan, mikä oli ollut myös vainajan selkeä toive. Aino kuvaa seuraavassa tuntemuksiaan miehensä kuoleman jälkeen:

Siis kun mä jotenkin uskon siihen, et mieheni on nyt päässyt sen Maijansa luokse. Että kun sehän oli hänelle hirveä paikka sillon aikanaan, et hänhän ei pystyny edes puhumaan vielä vuodenkaan jälkeen koko asiasta, et sit vasta ajan mittaan, et sit hän pysty puhumaan siitä kaikesta ja niiden entisestä elämästä. 
Ainon tapauksessa puoliso oli selvästi ilmaissut halunsa tulla haudatuksi edesmenneen puolison viereen. Suhteen jatkuminen useampaan edesmenneeseen omaan tai puolison puolisoon vaikeutti osassa kertomuksissa ymmärrystä siitä, kenen hautatahtoa tulisi noudattaa.

Uusperhetilanne vaikutti myös vainajan toiveisiin tuhkauksesta. Karin koko uuden parisuhteen ajan edesmennyt puoliso on ollut läsnä yhteisessä liitossa ja tämä vaikutti myös hautapaikan valintaan. Kari kertoo puolisonsa tuhkan sirottelusta:

No, siellä oli sisällä ihan tavallinen ruskea paperipussi, missä se tuhka oli. Se kaadetaan siitä sinne kuoppaan. Mä laitoin mullan päälle siihen. Niin se menee. Se oli samassa paikassa, missä hänen miehensä ... on haudattu ja hänen äitinsä.

Karin kertomus hautapaikasta kertoo siitä, että puolison edellinen liitto oli ollut ilmeisen merkittävä (vrt. Moss \& Moss, 1996). Puolison tuhka siroteltiin edesmenneen miehen kanssa samaan paikkaan, johon Karia ei itseään tulla hautaamaan. Aikaisempi tutkimus on korostanut, että käsitykset perheestä ovat muuttuneet ja on olemassa monia erilaisia suhdemalleja (Jallinoja \& Widmer, 2011). Uusperhetilanteessa eläneiden leskien tarinat osoittavat, että nämä muuttuvat suhdemallit vaikuttavat myös hautatahtoon.

Hautatavan ja hautauspaikan valintaan vaikuttivat myös vainajan persoona. Hanna kertoo miehensä tuhkan sirottelusta:

Sitten oli seuraava, että mereen, kun hän on kova purjehtija. Niinpä me sitten kesällä mentiin tonne majakalle, kun siellä hän on nuoruutensa purjehtinut, niin mentiin sinne. Mä olin sieltä kysynyt, että saadaanko me tulla sinne ja ripoteltiin sinne mereen se.

Erityisesti tarinat tuhkauksesta korostivat vainajan persoonan huomioimista sirottelupaikan yhteydessä. Tämä osoittaa, että haluttiin tehdä rituaalista persoonallinen ja tällä tavalla huomioida edesmenneen tahto. Aineistomme vahvistaa sen, että kansainvälisessä tutkimuksessa jo pidempään korostunut hautajaisten persoonallisuustrendi on tullut tärkeäksi myös Suomessa (vrt. Schäfer, 2007; Ramshaw, 2010; Caswell, 2011). 
Hautauspaikan valinnassa ei ollut ainoastaan kyse hautaustavasta vaan myös sen pohtimisesta, minne vainaja haudataan. Kyllikki kuvaa puolisonsa hautapaikan valintaa:

Sitten siinä Jaakon sängyn äärellä, kun Jaakko oli jo kuollu, näiden siskojen kanssa päätettiin, että kyllä Jaakon paikka on äidin ja isän kanssa, et ku tytöt sano, et he ei kumpikaan halua sinne. Siellä hän on nyt äidin ja isän kanssa.

Kyllikin puoliso päätettiin haudata sukuhautaan. Yllä oleva lainaus korostaa yhteistä pohdintaa, relationaalista autonomiaa, jossa huomioitiin vainajan mahdollinen toive, mutta myös saatavilla oleva tila sukuhaudassa. Kumpikaan sisarista ei halunnut tulla haudatuksi sukuhautaan ja tämä mahdollisti Jaakon hautauksen siihen. Tämä keskustelu osoittaa, että vainajan hautapaikan valinnasta eivät päättäneet yksin lesket vaan päätös tehtiin yhdessä lähipiirin kanssa. Relaatioissa ei ollut ainoastaan kyse vainajan ja läheisen välisestä tunnesiteestä vaan myös menetyksen kokeneiden keskinäisistä suhteista ja heidän yhteisestä ymmärryksestä siitä, mitä vainaja oli toivonut. Näiden lähirelaatioiden merkitys vainajan tahdon noudattamiseen vahvistaa kansainvälisen monitieteisen kuolematutkimuksen löytöjä (Ellis, 2013; Woodthorpe, 2017).

Perinteisesti tuhkausta on vastustettu joissakin kristillisissä kirkoissa sen perusteella, että polttohautauksen jäljiltä vainajan ruumis ei ole kokonainen ruumiin ylösnousemuksen aikana (Emke, 2002; Davies, 2017: 154-155). Tämä on yksi syy, miksi myös Suomessa tuhkausta kannattivat alun perin tieteellisen maailmankuvan kannattajat. Vapaa-ajattelijoiden kannatus lisäsi tuhkauksen vastustusta kristillisten kirkkojen piirissä (Lahtinen, 1989). Kukaan haastattelemistamme ei kuitenkaan korostanut tuhkauksen aiheuttaneen ongelmia maailmankatsomukselleen. Näyttääkin siltä, että tämän päivän Suomessa valinta tuhkauksen ja arkkuhautauksen välillä tehdään paljolti taloudellisista tai tilan puutteen syistä, ei katsomusten ohjaamana. Näin ainakin haastattelemiemme suomalaissyntyisten keskuudessa.

Suomessa tuhkausta tutkittiin 1980-luvulla Åbo Akademin tutkimusprojektissa, jossa määrällisellä kyselyllä kartoitettiin arkkuhautauksen ja tuhkauksen valintaa ja siihen vaikuttaneita syitä. Kaksi tärkeintä syytä olivat vainajan viimeinen toivomus ja omaisten päätös (Holm \& Lahtinen, 1985:22). Kyseessä oli siis vainajan hautatahdon noudattaminen hautaustavan valinnas- 
sa, sillä myös omaisten päätöksen taustalla on usein halu noudattaa vainajan toivetta. Kiinnostavaa on, että jo tuolloin vain pieni osa (4\%) perusteluista oli uskonnollisia ja näistä suurin osa kannatti arkkuhautausta. Arkkuhautausta perusteltiin selvästi enemmän perinteellä ( $28 \%$ ), johon vastaajien mukaan tuhkaus ei kuulunut (Holm \& Lahtinen, 1985:24). Tutkimuksemme tulokset osoittavat, että tuhkauksen yleistyttyä siitä näyttää tulleen hyväksytty hautaustapa ja osa suomalaista hautausperinnettä myös iäkkäiden suomalaisten keskuudessa.

Surevien suhteet vainajaan ja heidän keskinäiset suhteensa vaikuttivat siihen, millä tavalla vainajan tahto huomioitiin hautaustavan ja hautapaikan valinnassa. Edellä oleva keskustelu on osoittanut, että epäselvyys vainajan toiveista usein vaikeutti hautausprosessiin liittyviä valintoja. Läheiset eivät aina päässeet yhteisymmärrykseen siitä, mikä oli vainajan tahto. Useat olivat kertoneet omista toiveistaan suullisesti, mutta näistä suullisista toiveista saattoi läheisten kesken olla useita tulkintoja.

\section{Yhteenveto ja johtopäätökset}

Tämän artikkelin aineistona olivat menetyksen kohdanneiden ikäihmisten tarinat edesmenneen läheisensä hautatahdosta. Kohdistimme artikkelissa erityishuomion teologian ja oikeustieteen näkökulmiin kerrotuista läheissuhteista. Tulokset osoittivat, että teologia ja oikeustiede täydensivät näkemystä hautatahdosta ja sen noudattamisesta. Tämä näkyi erityisen selvästi katsomusten vaikutuksessa vainajan toiveisiin hautajaisista ja hautapaikasta. Katsomusten noudattamisessa on samalla kyse ihmisoikeuksien noudattamisesta ja samalla siinä on kyse teologiasta eli vainajan oman katsomuksen seuraamisesta. Teologiset relaatiot korostavat ihmis- ja jumalasuhteen merkitystä, oikeustieteelliset relationaalista eli yhdessä pohdittua autonomiaa. Tämän artikkelin tuloksissa nämä näkyivät esimerkiksi läheisten yhteisinä pohdintoina siitä, mikä oikeastaan oli vainajan toive hänen omien hautajaistensa suhteen.

Tässä artikkelissa raportoidut tarinat sisälsivät sekä tarinoita selkeästi ilmaistuista hautaussuunnitelmista, että oletetun hautatahdon ilmaisuista. Liki kaikki haastattelemamme läheiset pohtivat haastattelunsa aikana sitä, mitä edesmennyt vainaja oli toivonut hautajaisten ja hautapaikan osalta. Tästä huolimatta vain osa oli kirjannut selkeästi ylös omat toiveensa. Haastattelemistamme menetyksen kokeneista läheisistä suurin osa oli 65-75-vuotiaita, 
vain yksi haastateltavista oli täyttänyt 80 vuotta. Hautatahdon kunnioittamisessa iällä ei näyttänyt olevan kovin suurta merkitystä. Suurempi merkitys hautatahdon noudattamisessa oli uusperhetilanteella ja näissä myös viralliset uudet avioliitot toivat epäselvyyttä vainajan hautatahdon noudattamiseen, eivät ainoastaan ikäihmisten epäviralliset seurustelusuhteet.

Katsomukset vaikuttivat vainajan hautatoiveisiin erityisesti silloin kun hänellä oli ollut selvä uskonnollinen tai ei-uskonnollinen vakaumus. Läheisen oli helpompi noudattaa katsomustoivetta, jos hän jakoi vakaumuksen edesmenneen kanssa. Toisilla katsomus ei vaikuttanut kovinkaan paljon keskusteluun hautatahdosta. Näissä tapauksissa läheisellä ja vainajalla oli ollut eriävät näkemykset katsomuksen vaikutuksesta siunaustilaisuuteen tai kummallakaan ei ollut kovinkaan selkeää vakaumusta, joka olisi vaikuttanut hautajaisten muotoon tai hautapaikan valintaan. Katsomuksilla ei suoraan perusteltu tiettyjä valintoja hautajaisiin liittyen, vaan ne vaikuttivat laajemmin läheisten näkemyksiin vainajan toiveista. Tämä sama linja näkyy myös kansainvälisessä tutkimuksessa, jonka mukaan vain pieni osa perusteli valintoja suoraan uskonnollisella tai humanistisella katsomuksella (Holloway ym., 2013). Vainajan katsomuksia ei siten aina nähdä selkeinä toiveina hautajaisten suunnittelussa samalla tavoin kuin vaikka kirjallisena esitettyä hautatahtoa. Relaatioiden läheisyys näkyy myös siinä, kuinka hyvin läheiset tiesivät vainajan katsomustoiveet liittyen omiin hautajaisiinsa (Draper ym., 2013).

Tutkimuksemme vahvistaa näkemyksen, että evankelis-luterilaisella kirkolla on vielä hyvin vahva monopoli suomalaisissa hautauksissa. Tämä ei välttämättä ole hyvä vainajan hautatahdon näkökulmasta kirkkoon kuulumattomien osalta. Useampi kirkkoon kuulumaton vainaja ja läheinen olivat päätyneet kirkolliseen siunaukseen ainakin osittain perinteen vuoksi. Tämä näyttää vahvistavan aikaisempaa suomalaista tutkimusta, jonka mukaan kuuluminen evankelis-luterilaiseen kirkkoon ja erityisesti kirkollinen siunaus ovat tärkeitä (Butters, 2017). Suomessa kuuluminen kansankirkkoon on varsinkin vanhempien ikäpolvien mukaan tärkeää (Niemelä, 2015). Kansainvälinen tutkimus on jo parinkymmenen vuoden ajan keskustellut sekularisaation vaikutuksesta hautausrituaaleihin. Näissä tutkimuksissa on tullut ilmi, että useissa maissa hautaustoimiston työntekijät toimittavat uskonnottomia hautausrituaaleja (Emke, 2002; Schäfer, 2007). On kiinnostavaa nähdä, miten alan toimijat Suomessa vastaavat tähän uskonnottomien hautajaisten tarpeisiin. 
Uusperhetilanne hankaloitti vainajan hautatahdon noudattamista erityisesti niissä tilanteissa, joissa läheisillä oli erilaisia tulkintoja vainajan toiveista. Näissä tilanteissa hautatahdon noudattamisesta tuli riitaa ja tästä johtuen läheiset halusivat kertoa siitä haastattelussa. Erilaisia uusperhetilanteita oli usealla tämän aineiston haastateltavista. Nämä tarinat korostuvat tässä artikkelissa koska ne vaikuttivat niin paljon vainajan toiveisiin erityisesti hautapaikan valinnassa. Ikäihmisten uusperheet lisääntyvät ja tämä lisää kirjoitetun hautatahdon tarvetta.

Läheisen kuolema näytti myös synnyttävän halun ennakoida omaa kuolemaa ja ilmaista oma hautatahtonsa. Tästä kertoivat erityisesti uusperheessä menetyksen kokeneet, jotka olivat jääneet kaipaamaan selvää hautatahtoa järjestäessään hautajaisia. Aikaisempien oikeudenkäyntien perusteella tiedetään, että hautajaisia koskevat riidat päätyvät toisinaan oikeuden ratkaistavaksi (esim. Turun hovioikeus 7.10.2011 [S 11/769], ks. Mäki-Petäjä-Leinonen, 2013). Näyttäisi siltä, että virallinen paperi voi ehkäistä riitoja ja toimia vahvana näyttönä mahdollisessa oikeudenkäynnissä.

Tämän artikkelin aineisto muodostui menetyksen kokeneiden läheisten haastatteluista. Aihe on kuitenkin tärkeä myös niille ammattilaisille, kuten diakoniatyöntekijöille, jotka työssään tukevat kuolevia potilaita ja kohtaavat surevia omaisia. Näiden kohtaamisten lisäksi monet ammattilaiset myös neuvovat potilaita ja heidän omaisiaan oman elämän ennakoinnissa. Yksi tärkeä ennakoinnin muoto on kirjallisen hautatahdon ilmaiseminen. Mitä selvemmin potilas on ilmaissut toiveensa hautausrituaalista, hautatavasta ja hautapaikasta läheisilleen, sitä helpompi hautajaiset on järjestää. Tämä voi säs̈sää läheisiä riidoilta ja ikäviltä kokemuksilta hautajaisiin liittyen.

\section{Kiitokset}

Kiitämme Meaningful relations: Patient and family carer encountering death at home -hankkeen tiimiä yhteistyöstä aineistonkeruussa ja analyysiprosessissa. Kiitos Marjaana Seppäselle, Suvi-Maria Saarelaiselle, Mirja Sisko Anttoselle, Mia Niemelle, Sofia Sarivaaralle ja Sanna Mustasaarelle. 


\section{Lähteet}

Anneli 6/2017

Markku 8/2017

Eila, 6/2018

Kaarina, 6/2018

Kyllikki 6/2018; 12/2018

Aino 8/2018; 5/2019

Kari 8/2018; 5/2019

Ilmari 9/2018

Rita 9/2018

Matti 11/2018

Sari 8/2018

Hanna 11/2018

Sirpa 12/2018

Haastattelut aikajärjestyksessä, lisätiedoissa koodinimi ja haastattelujen ajoitus kuukauden tarkkuudella. Aineisto Meaningful relations-projektin hallussa.

\section{Kirjallisuus}

Baumeister, R. (1991). Meanings of life. New York: Guilford Press.

Brooks, J., McCluskey, S., Turley E. \& King, N. (2015). The utility of template analysis in qualitative psychology research. Qualitative Research in Psychology, 12(2), 202222. https://doi.org/10.1080/14780887.2 014.955224

Butters, M. (2017). Between east and west: a diachronic overview of Finnish death culture. Death Studies 41(1), 51-60. https:// doi.org/10.1080/07481187.2016.1257885

Caswell, G. (2011). Personalisation in Scottish funerals: Individualised ritual or relational process? Mortality, 16(3), 242-258. https://doi.org/10.1080/13576275.2011. 586124

Cooper-White, P. (2004). Shared wisdom; Use of the self in pastoral care and counselling. Minneapolis: Fortress press.

Cottam, H. (2011). Relational welfare. Soundings, 48(11), 134-144. https://doi. org/10.3898/136266211797146855
Davies, D. J. (2017). Death, Ritual and Belief. The Rhetoric of Funerary Rites. 3. painos. London: Bloomsbury.

Draper, P., Holloway, M. \& Adamson S. (2013). A qualitative study of recently bereaved people's beliefs about death: implications for bereavement care. Journal of Clinical Nursing, 23, 1300-1308. https:// doi.org/10.1111/jocn.12326

Ellis, J. (2013). Thinking beyond rupture: continuity and relationality in everyday illness and dying experience. Mortality, 18(3), 251-269. https://doi.org/10.1080/ 13576275.2013.819490

Frank, J. A. (1996). Preneed funeral plans: the case for uniformity. Elder Law Journal, $4(1), 1-54$.

Ganzevoort, R. (1998). Religious coping reconsidered part two: a narrative formulation. Journal of Psychology and Theology, 26(3), 276-286. https://doi. org/10.1177/009164719802600305

Ganzevoort, R. (2010). Minding the wisdom 
of ages: narrative approaches in pastoral care for the elderly. Practical Theology, 3(3), 331-340. https://doi.org/10.1558/ prth.v3i3.331

Harding, R. (2012). Legal constructions of dementia: discourses of autonomy at the margins of capacity. Journal of Social Welfare Eं Family Law, 34(4), 425-442. https:// doi.org/10.1080/09649069.2012.755031

Harrington, D. E. \& Krynski K. J., (2002). The effect of state funeral regulations on cremation rates: testing for demand inducement in funeral markets. Journal of Law and Economics, 45(1), 199-225. https://doi.org/10.1086/324652

Hautaustoimen tilasto (2019). https://www. kirkontilastot.fi/viz?id=135 - Viitattu 17.2.2020.

Hautaustoimilaki 457/2003. https://www. finlex.fi/fi/laki/ajantasa/2003/20030457 Viitattu 27.10.2020.

HE 204/2002. Hallituksen esitys eduskunnalle hautaustoimilaiksi. https://www. finlex.fi/fi/esitykset/he/2002/20020204 Viitattu 27.10.2020.

Holloway, M., Adamson S., Argyrou V., Draper P. \& Mariau D. (2013). "Funerals aren't nice but it couldn't have been nicer". The makings of a good funeral. Mortality, 18(1), 30-53. https://doi.org/10.1080/135 76275.2012.755505

Holm, N. G. \& Lahtinen, T. (1985). Arkkuhautaus vai tubkahautaus? Tutkimus hautaustavoista Suomessa. Religionsvetenskapliga Skrifter no. 8. Åbo: Åbo Akademi.

Jallinoja, R. \& Widmer E. D. (2011). Introduction. Jallinoja, R. \& Widmer, E. D. (toim.) Families and Kinship in Contemporary Europe. Rules and Practices of Relatedness. Palgrave Macmillan Studies in Family and Intimate Life. London: Palgrave Macmillan, 3-12. https://doi. org/10.1057/9780230307452_1

King, N. \& Brooks J. M. (2017). Template Analysis for Business and Management Students. London: SAGE Publications. https://doi.org/10.4135/9781473983304

Klass, D. (2006). Continuing conversations about continuing bonds. Death
Studies 30 (9), 843-858. Philadelphia: Taylor and Francis. https://doi. org/10.1080/07481180600886959

Klass, D., Silverman P. \& Nickman S. (toim.) (1996). Continuing bonds: new understandings of grief. New York: Routledge.

Ladd, K. L. (2007). Religiosity, the need for structure, death attitudes, and funeral preferences. Mental Health, Religion and Culture, 10(5), 451-472. https://doi. org/10.1080/13674670600903064

Lahtinen, T. (1989). Polttohautaus Suomessa; Aatehistoria ja kehitys. Religionsvetenskapliga Skrifter no. 18. Åbo: Åbo Akademi.

MacKenzie, C. \& Stoljar, N. (2000). Relational autonomy - Feminist perspectives on autonomy, agency and social self. Oxford: $\mathrm{Ox}-$ ford University Press.

McClure, B.J. (2010). Moving beyond individualism in pastoral care and counseling. Reflections on theory, theology, and practice. Eugene, OR: Cascade Books. https://doi. org/10.2307/j.ctt1cgdzjd

Moss, M. S. \& Moss, S. Z. (1996). Remarriage of widowed persons: a triadic relationship. - Klass, D., P. Silverman \& S. Nickman (toim.), Continuing Bonds: New Understandings of Grief. London: Taylor and Francis, 163-178.

Mäki-Petäjä-Leinonen, A. (2003). Dementoituvan henkilön oikeudellinen asema. Diss. Vammala: Suomalainen lakimiesyhdistys.

Mäki-Petäjä-Leinonen, A. (2013). Ikääntymisen ennakointi - Vanhuuteen varautumisen keinot. Helsinki: Talentum.

Nedelsky, J. (2011). Law's relations: $A$ relational theory of self, autonomy, and law. Oxford: Oxford University Press. https://doi.org/10.1093/acprof:oso/9780195147964.001.0001

Niemelä, K. (2015). "No longer believing in belonging": A longitudinal study of Finnish Generation Y from confirmation experience to Church-leaving. Social Compass, 62(2), 172-186. https://doi. org/10.1177/0037768615571688

Park, C. (2013). Religion and meaning. R. Paloutzian, \& C. Park (Toim.) Handbook of the psychology of religion and spirituality, 
2. painos. New York: The Guildford Press, 357-379.

Peltohaka, S. (1980). Nimenanto- ja hautaustavat Suomen Islam-seurakunnassa: uskontoantropologinen tutkimus tataarien siirtymäriiteistä. Pro gradu. Helsingin yliopisto: teologinen tiedekunta.

Punta, J. (1978). Kuolema, hautausrituaali ja surutavat Helsingin juutalaisilla: siirtymäriittiteorian sovellutus uskontoantropologiseen tutkimukseen. Pro gradu. Helsingin yliopisto: teologinen tiedekunta.

Ramshaw, E. (2010). The personalization of postmodern post-mortem rituals. Pastoral Psychology, 59(2), 171-178. https://doi. org/10.1007/s11089-009-0234-6

Schnell, T. (2009). Sources of meaning and meaning in life questionnaire (SoMe): Relations to de-mographics and well-being. The Journal of Positive Psychology, 4(6), 483-499. https://doi. org/10.1080/17439760903271074

Schäfer, C. (2007). Post-mortem personalization: pastoral power and the New Zealand funeral director. Mortality, 12 (1), 4-21. https://doi. org/10.1080/13576270601088319

Suomen testamenttikeskus oy (2020) Hau- tajaistestamentti. https://testamenttikeskus.fi/hautajaistestamentti/ - Viitattu 20.2.2020.

Tuominen, K., \& Pirhonen, J. (2019). "Who would take a 90-year-old?": community-dwelling nonagenarians' perceptions of social relationships. International Journal of Ageing and Later Life, 13(1), 111137. https://doi.org/10.3384/ijal.16528670.18387

Vaara, E., Haapola I., Seppänen M. \& Karisto A. (2016). What is wellbeing for the elderly? Naskali, P., Seppänen, M. \& Begum, S. (toim.) Ageing in the Arctic Climate Change and Well-being. London: Routledge, 55-79.

Valentine, C. (2008). Bereavement narratives. Continuing bonds in the twenty-first century. London: Routledge. https://doi. org/10.4324/9780203893364

Woodthorpe, K. (2017). Family and funerals: Taking a relational perspective. Death Studies, 41(9), 592-601. https://doi.org/10 $.1080 / 07481187.2017 .1325419$

Zylla, P. C. (2012). A pastoral theology of suffering. The roots of sorrow. Texas: Baylor University Press. 